\title{
Posidonia-based Compost as a Peat Substitute for Lettuce Transplant Production
}

\author{
Carlo Mininni and Pietro Santamaria \\ Dipartimento di Scienze Agro-Ambientali e Territoriali (DISAAT), University \\ of Bari “Aldo Moro," Via Amendola 165/A, 70126 Bari, Italy
}

Hamada M. Abdelrahman, Claudio Cocozza, and Teodoro Miano
Dipartimento di Scienze del Suolo, della Pianta e degli Alimenti (DISSPA),
University of Bari "Aldo Moro," Via Amendola 165/A, 70126 Bari, Italy

Francesco Montesano ${ }^{1}$ and Angelo Parente

National Research Council, Istituto di Scienze delle Produzioni Alimentari (CNR-ISPA), Via Amendola, 122/O, 70126 Bari, Italy

Additional index words. posidonia wastes, Posidonia oceanica Delile, compost, Lactuca sativa var. crispa, seedlings production, growing media

\begin{abstract}
Posidonia [Posidonia oceanica (L.) Delile] is a marine phanerogam endemic of the Mediterranean Sea that grows all along the coast forming extensive underwater meadows. Senescent posidonia leaves, together with fibers (residues of rhizomes and decomposed leaves), periodically accumulate along Mediterranean beaches, covering vast areas of coast. Removal and disposal of these large volumes of plant biomasses represent a high cost for local administrations. Therefore, in this experiment, beached residues of posidonia were composted with olive pruning and green wastes with the objective to assess the efficacy of posidonia-based compost (63\% on a volume basis) as a peat replacement. The compost was then mixed with a peat-based commercial substrate at rates of $0 \%(\mathrm{C} 0$, pure peat-based commercial substrate tested as control), $25 \%(\mathrm{C25})$, $50 \%$ (C50), 75\% (C75), and 100\% (C100, pure posidonia-based compost) v/v. Mixtures were used as growing media to produce lettuce seedlings for transplant. Two lettuce cultivars (8511RZ and Satine) were tested. Main physical and chemical properties of the five growing media, shoot and root fresh and dry weight, leaf area, root morphology, and elemental leaf tissue composition were studied. Growing media containing posidoniabased compost, C25 and C50 in particular, showed good physical properties. Increasing compost proportions in the mixtures resulted in enhanced: 1) availability of macro- and micronutrients in the growing media; and 2) overall growth parameters of lettuce seedlings, in particular for the cultivar Satine. In conclusion, posidonia-based compost shows a considerable potential as a peat substitute in horticultural substrates; posidonia residues are a low-cost renewable material. In growing media for lettuce seedlings production, posidonia-based compost could be used as a complement to peat at a rate of $\mathbf{2 5 \%}$ or $\mathbf{5 0 \%}$ to obtain optimal physical properties and to limit the negative effects of high $B$ content, which are typical of posidonia residues.
\end{abstract}

The most common substrate used in horticulture for growing seedlings and soilless plants cultivation is peat, alone or in mixture (Chavez et al., 2008), because of its good chemical and physical properties. Unfortunately, peat is a very expensive material, especially in Mediterranean countries, because it is imported mainly from northern and central Europe. Germany, Italy, and The

Received for publication 30 May 2012. Accepted for publication 7 Aug. 2012.

This work has been supported by project Life09 ENV/IT/000061 "Posidonia Residues Integrated Management for Eco-sustainability" (PRIME) co-financed by the European Commission.

We thank Gerolmina Florio for her technical assistance.

${ }^{1}$ To whom reprint requests should be addressed; e-mail francesco.montesano@ispa.cnr.it.
Netherlands are the main users of peat in Europe (Orfeo and Orlandi, 2009). Furthermore, peat is a non-renewable resource and its extraction can degrade wetlands ecosystems so that European policy strongly encourages the use of peat alternatives (Bustamante et al., 2008; Grigatti et al., 2007). As a consequence, the EU Commission (2001) decision states that to receive the European Union "eco-label," growing media (including soil improvers) should not contain any peat materials, encouraging the use of organic matter derived from the processing and/or re-use of waste (EU Commission, 2006).

Numerous studies have sought to identify alternatives to peat, focusing on renewable, locally available and low-cost materials derived from renewable and local available lowcost sources. Several waste materials can be successfully used, after composting, as alternative growing media for transplant production
(Bernal-Vicente et al., 2008; Bustamante et al., 2008; Ribeiro et al., 2007; SánchezMonedero et al., 2004). Through this oxidative transformation of organic wastes, nutrients are retained onto humic-like substances of the composted materials thus providing an appropriate level of available nutrients that could reduce fertilizer consumption and costs. Furthermore, composts tend to have good porosity and aeration properties (Chong, 2005), to improve the organic matter content of the substrates (Qazi et al., 2009), and to provide nutrients and growth regulators (PerezMurcia et al., 2006). On the other hand, composts characterized by a high salinity level can negatively affect the germination of seeds and the growing of seedlings when used as a substrate component (Ribeiro et al., 2007).

Posidonia [Posidonia oceanica (L.) Delile] is a marine phanerogam endemic of the Mediterranean Sea that grows all along the coast forming extensive meadows (Duarte, 1991). Every year, mostly in the fall, posidonia leaves senesce and detach off the rhizomes so that, in many areas, very conspicuous wedge-shaped deposits of posidonia debris are beached along vast areas of the coast ranging from a few centimeters in the water to several meters inshore (Ott, 1980).

According to Duarte (2004), a 1-km wide belt of seagrass may delivery an excess of $125 \mathrm{~kg}$ of dry seagrass material per meter of coastline each year. The large volumes of the beached plant residues along the Mediterranean coasts in Italy (De Falco et al., 2008; Mininni et al., 2009) represent a serious concern for the local authorities for a number of environmental, social, and economical implications. Common national regulations consider these plant biomasses as a special kind of solid waste material to be disposed into landfills, thus resulting in an enormous loss of organic materials, nutrients, and useful biomolecules (Saidi et al., 2009) and also in additional problems transferred to the waste dumps (Castaldi and Melis, 2004).

The greenhouse nurseries' production of seedlings in containers is a highly competitive business, where uniform seedling emergence and rapid growth are essential for efficient productions. Therefore, the use of good growing media appears crucial for achieving positive results (Sterrett, 2001).

The vegetable transplant industry relies entirely on soilless media for seedling production and peat represents the most widely used growing media. The impact of the substrate costs on the production of plants varies from $12 \%$ to $22 \%$, depending on the type of plant and cultivation technique (Zaccheo and Cattivello, 2009). Previous studies showed the positive chemical features and the absence of phytotoxicity phenomena (Cocozza et al., 2011a) and the good overall qualities of posidonia residue-based compost (Orquin et al., 2001; Saidi et al., 2009). Posidoniabased compost has been used in horticulture for greenhouse tomato (Castaldi and Melis, 2004; Verlodt et al., 1984) and lettuce (Gizas et al., 2012) cultivation, and for nursery production (Ben Jenana et al., 2009). 
The objectives of the present study were: 1) to evaluate the main physical and chemical properties of five growing media obtained by mixing posidonia-based compost and peat in different ratios; and 2) to ascertain the potential use of these substrates as growing media for commercial lettuce seedling production.

\section{Materials and Methods}

Compost. Posidonia-based compost, used as a component of growing media for this experiment, was obtained by mixing recently beached posidonia leaves ( $63 \%$ by volume) with olive pruning ( $21 \%$ by volume) and green wastes ( $16 \%$ by volume).

One pile of $\approx 4 \mathrm{~m}^{3}$ was prepared respecting the microbial requirements in terms of carbon/nitrogen (35 to 45) and moisture content $(55 \%$ to $65 \%)$.

The temperature of the windrow was kept $\geq 55{ }^{\circ} \mathrm{C}$ for at least $3 \mathrm{~d}$ by turning and irrigating the piles periodically to obtain the pasteurization of the biomasses. The active phase of composting was considered completed after $\approx 3$ weeks, when the temperature of the pile decreased naturally to a value less than $40{ }^{\circ} \mathrm{C}$. The curing phase was characterized by less frequent turning and continued until the 90th day to achieve further stabilization and obtain the final products (Cocozza et al., 2011a).

Experimental design. The trial was conducted in a plastic (polymethacrylate) greenhouse, with temperature control, at the "La Noria" experimental farm of the CNR-ISPA at Mola di Bari (lat. $41^{\circ} 03^{\prime} \mathrm{N}$, long. $17^{\circ} 04^{\prime} \mathrm{E}$, $24 \mathrm{~m}$ a.s.1.).

Five growing media were prepared and studied: posidonia-based compost was mixed with a peat-based commercial substrate (Brill Type 3 Special, mix of different peats added with $1 \mathrm{~kg} \cdot \mathrm{m}^{-3}$ PIG-MIX 14N-16P-18K fertilizer) at rates of $25 \%(\mathrm{C} 25), 50 \%$ (C50), and $75 \%$ (C75), and 100\% (C100, pure posidoniabased compost, without any fertilizer) $\mathrm{v} / \mathrm{v}$; pure peat-based commercial substrate $(\mathrm{C} 0)$ was tested as a control.

Two cultivars of lettuce (Lactuca sativa var. crispa) were used, '8511RZ' and 'Satine' [Rijk Zwaan Italia s.r.l., Calderara di Reno (BO), Italy] with the aim to test the treatments in comparison on plant material with a wider genetic base and to obtain reliable results.

Polystyrene plug trays ( 160 cells per tray with diameter of $2.5 \mathrm{~cm}$ and volume of $21 \mathrm{~mL}$ ) were filled with the five growing media tested in the experiment. The seeds were sowed on 16 Mar. 2009, one per cell. Each tray, filled with a specific substrate, was seeded with one cultivar. After sowing, the seeds were covered with vermiculite. The experiment was carried out following a randomized block design with three replications. In total, 30 trays were prepared (five growing media $x$ two cultivars $\times$ three replications), each tray representing an experimental unit.

Measurements and analytical methods. Germination and growth of seedlings was performed in the greenhouse. Minimum temperature was set to $10{ }^{\circ} \mathrm{C}$. The seedlings were irrigated daily with fresh water by means of a mobile sprinkler system. No additional fertigation was used for all the treatments.

The percentage of germination was determined by counting daily the number of germinated seeds for $14 \mathrm{~d}$ starting $48 \mathrm{~h}$ from seeding.

The experiment was ended $41 \mathrm{~d}$ after sowing (DAS) when, on average, the seedlings reached the commercial transplanting size. Twelve plants per treatment, four per replication, were harvested at random from each plug tray and used for biometric measurements, avoiding those placed next to the edge.

To characterize the aerial part, the leaf area was determined on scanned leaves using an Epson Perfection V700 scanning system and processing the images by an image analysis software (WinFolia; Régent Instruments, Canada). Likewise, roots of the same plants were washed carefully from the attached particles of substrate with distilled water, scanned, and analyzed using the WinRhizo image analysis software (Régent Instruments) to measure parameters describing root morphology (root volume, length, surface area, mean diameter, and number of tips).

Roots and shoots were weighted to determine fresh weight and then dried in a thermo-ventilated oven at $65{ }^{\circ} \mathrm{C}$ until reaching a constant mass; the dry weight of roots and shoots was measured.

The aerial part of plants remaining on each plug tray, except for those placed close to the edge, was used for tissues analysis; plant shoots were harvested, weighted, and dried as described previously. Dried material was weighted and ground through a mill (IKA; Labortechnik, Staufen, Germany) with a 1 -mm sieve.

The main physical properties of the five growing media [dry bulk density (BD), total pore space (TPS), particle density (PD), air capacity (AC), and water-holding capacity (WC)] were determined according to the European Standard 13040 (1999). Briefly, the materials were equilibrated in water and then transferred in tubes made with two overlapping polyvinyl chloride rings $(100 \pm 1 \mathrm{~mm}$ diameter and $50 \pm 1 \mathrm{~mm}$ height each). After having filled up, the double rings were saturated with water for $48 \mathrm{~h}$ and then transferred into a sandbox (Eijkelkamp Agrisearch Equipment, Giesbeck, The Netherlands) at $-10 \mathrm{~cm}$ pressure head $(-1 \mathrm{kPa})$ for $48 \mathrm{~h}$. Thereafter, the double rings were removed from the sandbox and separated. The lower rings were weighted and dried at $105{ }^{\circ} \mathrm{C}$ to constant mass. Easily available water (EAW) and water buffer capacity (WBC) were determined by increasing the values of suction pressure in the sandbox at -50 and $-100 \mathrm{~cm}(-5$ and $-10 \mathrm{kPa}$, respectively). Compacted bulk density was measured according to the European Standard 13040 (1999).

Electrical conductivity (EC) and $\mathrm{pH}$ were analyzed on water-soluble extract or suspension $(1: 5, \mathrm{v} / \mathrm{v})$ of growing media according to European Standard 13038 (1999) and European Standard 13037 (1999), respectively. The extracts were analyzed also for $\mathrm{N}-\mathrm{NO}_{3}$, potassium $(\mathrm{K})$, calcium $(\mathrm{Ca})$, magnesium $(\mathrm{Mg})$, and sodium $(\mathrm{Na})$ content using ion chromatography (Dionex DX120; Dionex Corporation, CA)

The ash content of the growing media, expressed as a percentage of the initial dry weight, was determined by combustion in a Controls 10-D1418/A muffle furnace (Cernusco sul Naviglio, Italy) at $550{ }^{\circ} \mathrm{C}$ for $12 \mathrm{~h}$.

Total nitrogen $\left(\mathrm{N}_{\text {tot }}\right)$ content of substrates and shoot tissues was obtained by two Kjeldahl distillations (Kjeldahl, 1883): the first one using the Devarda's alloy to reduce nitrates and nitrites and the second one to obtain the total Kjeldahl $\mathrm{N}$ (sum of organic $\mathrm{N}$ and ammonium). Organic carbon $\left(\mathrm{C}_{\text {tot }}\right)$ content of growing media was determined by dichromate oxidation and subsequent titration with ferrous sulphate (Springer and Klee, 1954). The total $\mathrm{P}$ content was determined by digestion of substrate samples in a mixture of high-purity grade concentrated $\mathrm{HNO}_{3}, \mathrm{HCl}$, and $\mathrm{H}_{2} \mathrm{O}_{2}(5: 2: 1)$ and filtration through Whatman 42 . The blue color in the filtered solution was developed with successive additions of an ammonium molybdatesulfuric acid solution and then an ascorbic acid solution and measured at $650 \mathrm{~nm}$ (Olsen et al., 1954).

The concentrations of major $[\mathrm{K}, \mathrm{Ca}, \mathrm{Mg}$, iron $(\mathrm{Fe})$, and $\mathrm{Na}$ ] and trace [copper $(\mathrm{Cu})$, manganese $(\mathrm{Mn})$, zinc $(\mathrm{Zn})$, boron $(\mathrm{B})$, cadmium $(\mathrm{Cd})$, chromium $(\mathrm{Cr})$, nickel $(\mathrm{Ni})$, and lead $(\mathrm{Pb})$ ] elements in the growing media and in the shoot tissues were assessed by optical emission spectroscopy inductively coupled plasma (OES-ICP) measurements using an iCAP 6000 Series ICP-OES Spectrometer (Thermo Electron Corporation, Newington). Samples for ICP analysis were previously digested in a mixture of high-purity grade concentrated $\mathrm{HNO}_{3}, \mathrm{HCl}$ and $\mathrm{H}_{2} \mathrm{O}_{2}(5: 2: 1)$ and then filtered through Whatman 42 .

Statistical analysis. According to the research objectives and as equal increments between successive levels of the independent variable were applied, the analysis of variance with linear, quadratic, and cubic orthogonal polynomials was performed on all data (Steel and Torrie, 1988). Data were subjected to SAS's (Cary, NC) general linear model procedure.

\section{Results and Discussion}

Physical and chemical characteristics of the growing media. Physical properties of growing media are reported in Table 1; they showed, in general, good physical properties, as compared with an ideal growing media (Abad et al., 2001; De Boodt and Verdonck, 1972), in particular for $\mathrm{C} 0, \mathrm{C} 25$, and $\mathrm{C} 50$ treatments.

Increasing the compost percentage in the growing media raised TPS, AC, and PD following a linear, quadratic, and cubic trend, respectively; on the other hand, a decrease 
was observed for WC and WBC (quadratically trend), whereas BD reduced following a cubic trend; EAW increased slightly up to $50 \%$ of compost rate in the mixture but decreased strongly at a higher compost rate following a quadratic trend (Table 1). AC represents a limiting factor for soilless growing media, in particular for seedling production in small-sized cells; in fact, although a limited WC could be managed through appropriate irrigation, a low AC could not (Fonteno, 1996). These characteristics are related to the fibrous nature of posidonia residues (Cocozza et al., 2011b), and similar physical characteristics were observed for other biomasses such as coconut coir dusts (Abad et al., 2005), kenaf core, and rice hulls (Tsakaldimi, 2006). However, the composting process slightly modified some physical properties of material, decreasing TPS and $\mathrm{AC}$ and increasing $\mathrm{WC}$, because of the particle size modifications.

The chemical features of the peat and posidonia-based compost growing media are reported in Table 2. The highest content of main macro- and microelements $(\mathrm{P}, \mathrm{Ca}, \mathrm{Mg}$, $\mathrm{Na}, \mathrm{Fe}, \mathrm{Cu}, \mathrm{Mn}, \mathrm{Zn}, \mathrm{B}, \mathrm{Cd}, \mathrm{Cr}, \mathrm{Ni}$, and $\mathrm{Pb}$ ) in substrates containing compost reflected the ash concentration and indeed influenced the EC value. The heavy metal concentrations in pure posidonia-based compost (C100) were well below the thresholds provided by the Italian legislation (Cocozza et al., 2011a), suggesting safe use in agriculture.
The relatively higher content of the alkaline elements, especially $\mathrm{Ca}, \mathrm{Mg}$, and $\mathrm{Na}$, in compost-based growing media could have influenced their $\mathrm{pH}$, slightly higher in comparison with pure peat-based commercial substrate and to the reference range (5.2 to 6.3) suggested by Abad et al. (2001). On the other hand, $\mathrm{C}_{\text {tot }}$ and $\mathrm{K}$ contents decreased following a cubic trend with increasing compost in the mixture, whereas the $\mathrm{N}_{\text {tot }}$ content did not present any variations (Table 2).

The substrate EC raised linearly with increasing compost percentages in the growing media, together with the ash content (cubic trend) and, consequently, main macro- and microelement concentrations. However, the EC values of all growing media remained below $0.5 \mathrm{dS} \cdot \mathrm{m}^{-1}$, the limit for an ideal growing media suggested by Abad et al. (2001), despite the marine origin of the posidonia plant. To obtain a posidonia-based compost with relatively low EC value, no pre-treatment was applied to the posidonia debris to reduce the initial high salinity; instead, water was added to the pile either to restore moisture or to leachate salts during the composting process, as reported by Cocozza et al. (2011a).

The B content increased following a quadratic trend when increasing compost presence in the growing media, reaching an extremely high concentration in $\mathrm{C} 100$. High $\mathrm{B}$ content in the posidonia-based compost is possibly ascribed to the high concentration of

Table 1. Physical properties of five growing media with increasing posidonia-based compost percentage.

\begin{tabular}{|c|c|c|c|c|c|c|c|}
\hline & TPS & $\mathrm{WC}$ & $\mathrm{AC}$ & EAW & WBC & $\mathrm{BD}$ & PD \\
\hline & \multicolumn{5}{|c|}{$(\%)$} & \multicolumn{2}{|c|}{$\left(\mathrm{g} \cdot \mathrm{cm}^{-3}\right)$} \\
\hline Ideal substrate & $>85$ & 55 to 70 & 20 to 30 & 20 to 30 & 4 to 10 & 0.400 or less & 1.4 to 2.0 \\
\hline \multicolumn{8}{|l|}{ Substrate $^{\mathrm{y}}$} \\
\hline $\mathrm{C} 0$ & 91.9 & 72.3 & 19.6 & 21.8 & 5.40 & 0.131 & 1.61 \\
\hline $\mathrm{C} 25$ & 92.4 & 66.6 & 25.8 & 22.7 & 5.50 & 0.126 & 1.66 \\
\hline $\mathrm{C} 50$ & 92.6 & 57.7 & 35.0 & 23.6 & 4.23 & 0.125 & 1.69 \\
\hline $\mathrm{C} 75$ & 93.1 & 42.5 & 50.6 & 14.3 & 3.13 & 0.121 & 1.75 \\
\hline C100 & 93.9 & 29.9 & 64.0 & 8.9 & 1.47 & 0.106 & 1.73 \\
\hline Significance $^{\mathrm{x}}$ & $\mathrm{L} * * *$ & $\mathrm{Q}^{* *}$ & $\mathrm{Q}^{* *}$ & $\mathrm{Q}^{* * *}$ & $\mathrm{Q}^{* *}$ & $\mathrm{C}^{*}$ & $\mathrm{C}^{* * *}$ \\
\hline
\end{tabular}

${ }^{\mathrm{z} A c c o r d i n g}$ to Abad et al. (2001) and De Boodt and Verdonck (1972).

${ }^{\mathrm{y}} \mathrm{C} 0=100 \%$ peat-based commercial substrate; $\mathrm{C} 25=25 \%$ posidonia-based compost $+75 \%$ peat-based commercial substrate; $\mathrm{C} 50=50 \%$ posidonia-based compost $+50 \%$ peat-based commercial substrate; $\mathrm{C} 75=75 \%$ posidonia-based compost $+25 \%$ peat-based commercial substrate; $\mathrm{C} 100=100 \%$ posidoniabased compost. Percentages are expressed on the basis of volume.

${ }^{\mathrm{x}}$ Linear (L), quadratic (Q) or cubic (C) trend. *,**,***significant at the $5 \%, 1 \%$, or $0.1 \%$ level of probability, respectively.

$\mathrm{TPS}=$ total pore space; $\mathrm{WC}=$ water capacity; $\mathrm{AC}=$ air capacity; $\mathrm{EAW}=$ easily available water; $\mathrm{WBC}=$ water buffer capacity; $\mathrm{BD}=$ dry bulk density; $\mathrm{PD}=$ particle density. this element in posidonia debris (Cocozza et al., 2011b).

The growing media extracts showed a linear increase of the $\mathrm{N}-\mathrm{NO}_{3}$ content, whereas $\mathrm{Mg}$ and $\mathrm{Na}$ raised quadratically with increasing percentage of compost in the substrates. On the other hand, the concentration of $\mathrm{K}$ decreased following a linear trend from $\mathrm{C} 0$ to C100 (Table 3).

Seed germination, plant growth, and tissue composition. Lettuce seed germination was not influenced by growing media composition; in fact, $13 \mathrm{DAS}$, the germination for both the cultivars was $100 \%$ in all the substrates (data not shown).

In general, the two cultivars tested showed differences in values of measured growth parameters as a direct consequence of their different genotype. In fact, 'Satine' had on average higher shoot fresh weight, root fresh and dry weight, and root/shoot ratio. The higher shoot fresh weight of 'Satine' was probably the result of more aqueous tissues, because no differences were found on a dry basis, and higher shoot dry matter percentage was observed in '8511RZ', which showed also higher leaf area (Table 4).

In general, significant increases in the growth of plants with increasing compost presence in the mixtures were observed (Table 4). On average, fresh and dry weight of both shoot and root and leaf area of seedlings increased with increasing compost in growing media. On the contrary, the shoot dry matter percentage decreased quadratically, indicating a higher presence of water in tissues of plants grown on compost (Table 4). The root dry matter percentage was different among treatments with the lowest value in C50 (Table 4). A close relation between the leaf area and the dry weight of shoot has been documented by Tremblay and Senècal (1988). The increases of shoot fresh weight and leaf area with increasing compost presence in growing media were more remarkable in 'Satine' than in '8511RZ' (Fig. 1). On average, root/shoot ratio linearly decreased with increasing posidonia-based compost presence in growing media; however, this effect of compost was more remarkable in 'Satine', in which the root/shoot value decreased from 1.4 in $\mathrm{C} 0$, to 0.9 in $\mathrm{C} 100$ (omitted figure). Mineral nutrient supply can strongly affect plant morphology. In particular, increasing $\mathrm{N}$ and $\mathrm{P}$ supply enhances both shoot and root

Table 2. Chemical characteristics of five growing media with increasing posidonia-based compost percentage.

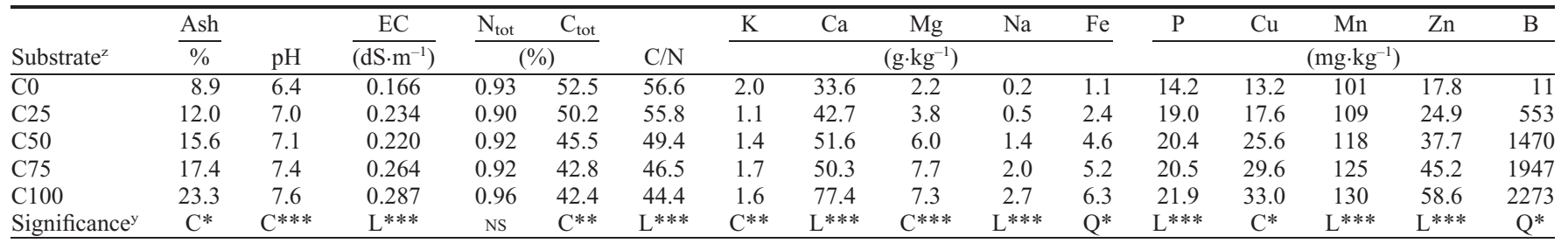

${ }^{z} \mathrm{C} 0=100 \%$ peat-based commercial substrate; $\mathrm{C} 25=25 \%$ posidonia-based compost $+75 \%$ peat-based commercial substrate; C50 $=50 \%$ posidonia-based compost $+50 \%$ peat-based commercial substrate; $\mathrm{C} 75=75 \%$ posidonia-based compost $+25 \%$ peat-based commercial substrate; $\mathrm{C} 100=100 \%$ posidonia-based compost. Percentages are expressed on the basis of volume.

${ }^{y}$ Linear (L), quadratic (Q) or cubic (C) effect. Ns, *, **, *** Nonsignificant or significant at the $5 \%, 1 \%$, or $0.1 \%$ level of probability, respectively. $\mathrm{EC}=$ electrical conductivity; $\mathrm{N}_{\text {tot }}=$ total nitrogen; $\mathrm{C}_{\text {tot }}=$ organic carbon; $\mathrm{K}=$ potassium; $\mathrm{Ca}=$ calcium; $\mathrm{Mg}=$ magnesium; $\mathrm{Na}=$ sodium; $\mathrm{Fe}=$ iron; $\mathrm{P}=$ phosphorus; $\mathrm{Cu}=$ copper; $\mathrm{Mn}=$ manganese; $\mathrm{Zn}=$ zinc; $\mathrm{B}=$ boron . 
growth, but usually the shoots grow more than root apparatus, leading to a typical fall in root/shoot ratio (Marschner, 1995). Although the $\mathrm{N}_{\text {tot }}$ content in growing media was not influenced by compost addition (Table 2), increasing presence of posidonia-based compost

Table 3. Chemical composition of the water-soluble extract $(1: 5, \mathrm{v} / \mathrm{v})$ of five growing media with increasing posidonia-based compost percentage.

\begin{tabular}{|c|c|c|c|c|c|}
\hline \multirow[b]{2}{*}{ Substrate $^{z}$} & $\mathrm{~N}-\mathrm{NO}_{3}$ & K & $\mathrm{Ca}$ & $\mathrm{Mg}$ & $\mathrm{Na}$ \\
\hline & \multicolumn{5}{|c|}{$\left(\mathrm{mg} \cdot \mathrm{L}^{-1}\right)$} \\
\hline$\overline{\mathrm{C} 0}$ & 1.38 & 31.28 & 52.21 & 6.03 & 5.73 \\
\hline $\mathrm{C} 25$ & 4.19 & 33.17 & 54.22 & 12.46 & 31.25 \\
\hline C50 & 4.28 & 26.97 & 59.58 & 16.09 & 33.73 \\
\hline C75 & 5.83 & 24.96 & 53.96 & 20.39 & 45.47 \\
\hline $\mathrm{C} 100$ & 7.14 & 17.75 & 45.34 & 22.22 & 50.39 \\
\hline Significance $y$ & $\mathrm{~L}^{* * *}$ & $\mathrm{~L}^{* * *}$ & NS & $\mathrm{Q}^{* *}$ & $\mathrm{Q}^{* *}$ \\
\hline $\begin{array}{l}{ }^{ } \mathrm{C} 0=100 \% \mathrm{p} \\
25 \% \text { posidoni } \\
\text { commercial st } \\
\text { compost }+50 \\
\mathrm{C} 75=75 \% \mathrm{pc} \\
\text { based commer } \\
\text { based compos } \\
\text { basis of volun } \\
\text { 'Linear (L) o } \\
\text { Nonsignifican } \\
\text { probability, re } \\
\mathrm{K}=\text { potassiun } \\
\mathrm{Na}=\text { sodium. }\end{array}$ & $\begin{array}{l}\text { a-based } \\
\text { dbstrate; } \\
\% \text { peat-b } \\
\text { osidonia-- } \\
\text { cial substr } \\
\text { t. Percen } \\
\text { ne. } \\
\text { r quadra } \\
\text { tor signi } \\
\text { spectivel } \\
\text { n; } \mathrm{Ca}=\mathrm{c}\end{array}$ & $\begin{array}{l}\text { based c } \\
\text { based } \\
\text { rate; } C 1 \\
\text { atages } \\
\text { tic (Q) } \\
\text { ficant a } \\
\text { ly. } \\
\text { calciun }\end{array}$ & $\begin{array}{l}50 \% \text { po } \\
\text { ommer } \\
\text { ompos } \\
00=10 \\
\text { are exp } \\
\text { effect } \\
1 \% \text { or }\end{array}$ & $\begin{array}{l}t+25 \% \\
0 \% \text { posi } \\
\text { ressed } \\
\text { NS, } \\
0.1 \% \text { le }\end{array}$ & $\begin{array}{l}\text {-based } \\
\text {-based } \\
\text { strate; } \\
\text { o peat- } \\
\text { donia- } \\
\text { on the } \\
\text { *, *** } \\
\text { evel of } \\
\text { esium; }\end{array}$ \\
\hline
\end{tabular}

in the substrates increased $\mathrm{N}$ concentration in leaf tissues (see below). In fact, the posidonia-based media released a higher amount of $\mathrm{N}-\mathrm{NO}_{3}$, as confirmed by the water extracts analyses (Table 3 ). It should also be pointed out that the high root/shoot ratio under $\mathrm{C} 0$ treatment was mainly the result of the low shoot growth, but not the high root growth (Table 4). The increase in seedling biomass production with the use of compost as a growing media component has been also reported by other authors (Bustamante et al., 2008; Perez-Murcia et al., 2006); this effect could be attributed to the great input of nutrients provided by composts, in particular in this experiment $\mathrm{P}, \mathrm{Ca}, \mathrm{Mg}, \mathrm{Fe}, \mathrm{Cu}, \mathrm{Mn}$, and $\mathrm{Zn}$ (Table 2). Taking into account that no extra fertilization has been provided in this experiment, the high growth rate of plants in the presence of posidonia-based compost suggests the possibility to reduce external mineral fertilizers input, because of the excellent endowment of nutrients of this material.

As observed for the shoot, on average, the Satine cultivar showed a more developed root system compared with '8511RZ' (Table 5).

Root morphology parameters were influenced by mixture composition with a general linear enhancement of root growth with increasing presence of compost in growing

Table 4. Shoot, root, and root:shoot ratio (R/S) of the seedlings of two lettuce cultivars grown on five growing media with increasing posidonia-based compost percentage.

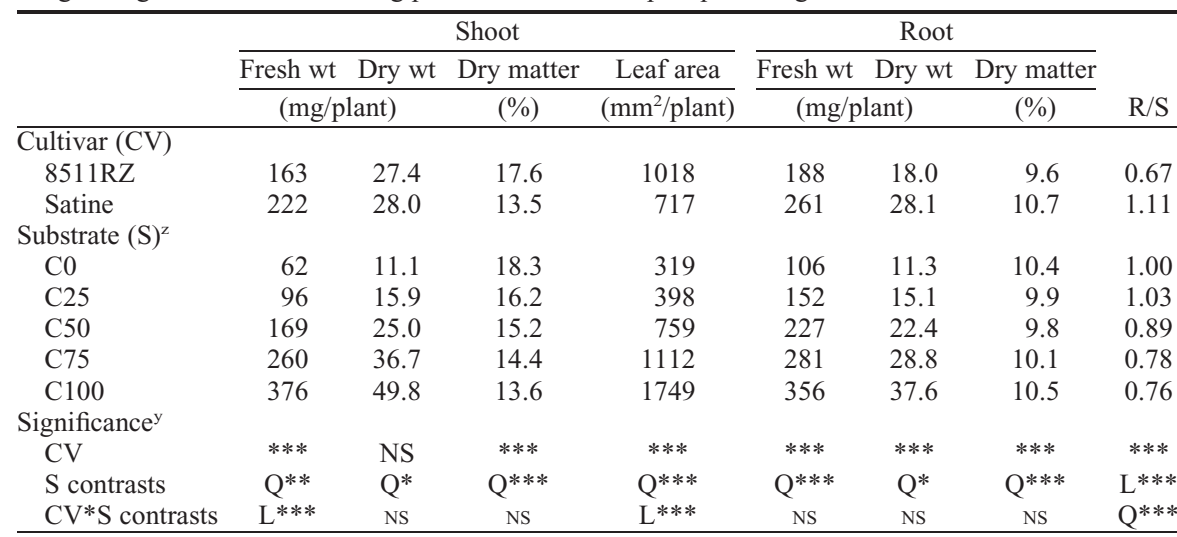

${ }^{\mathrm{z}} \mathrm{C} 0=100 \%$ peat-based commercial substrate; $\mathrm{C} 25=25 \%$ posidonia-based compost $+75 \%$ peat-based commercial substrate; $\mathrm{C} 50=50 \%$ posidonia-based compost $+50 \%$ peat-based commercial substrate; $\mathrm{C} 75=75 \%$ posidonia-based compost $+25 \%$ peat-based commercial substrate; $\mathrm{C} 100=100 \%$ posidoniabased compost. Percentages are expressed on the basis of volume.

${ }^{y}$ Linear (L) or quadratic (Q) trend for the substrate effect. Ns, *, **, *** Nonsignificant or significant at the $5 \%, 1 \%$, or $0.1 \%$ level of probability, respectively. media in terms of root length, surface area, mean diameter, volume, and number of tips (Table 5). However, 'Satine' resulted in a more positive response to compost proportions than '8511RZ' (Fig. 2).

In general, transplants with well-developed root systems are reported to recover more quickly from transplant shock (Weston and Zandstra, 1986); in fact, this represents a crucial point for the quality of seedlings for transplant. Furthermore, root surface area is an important factor for root uptake and the number of tips per root system may also play a role in solute uptake (Redjala et al., 2011). Root morphology is known to be influenced by water and nutrient availability as well by external applications of hormones (LópezBucio et al., 2003). Root growth and branching is favored in nutrient-rich environments and in the presence of hormones, in particular auxins, and hormone-like compounds; this enables plants to optimize the exploitation of available resources, which are in turn transformed into photoassimilates and transported again to the root, consequently influencing plant growth and morphology in a systemic manner (Forde and Lorenzo, 2001). It is evident that development of such morphology in the seedlings was favored by the application of nutrient-rich and biologically active substrates like compost as compared with peat (Lazcano et al., 2009). It is also clear that good physical properties (e.g., TPS, AS, BD) of posidonia-based compost enhanced root penetration capacity and, in general, promoted their development. When BD increases, the number of larger pores is reduced, and the forces of the roots necessary for deformation and displacement of substrate particles readily become limiting and root elongation rates decrease (Taylor and Ratliff, 1969).

Furthermore, the overall increased growth of plants in presence of posidonia-based compost could be presumably related to the presence of compounds with biostimulant activity in the compost. In fact, biostimulant properties have been found in Posidonia australis (Intellectual Property in Australia, 2012), a marine plant species close to Posidonia oceanica used for compost production in our experiment.

Table 6 shows the effects of growing media studied on the elemental composition of lettuce shoot tissues. On average, 'Satine'
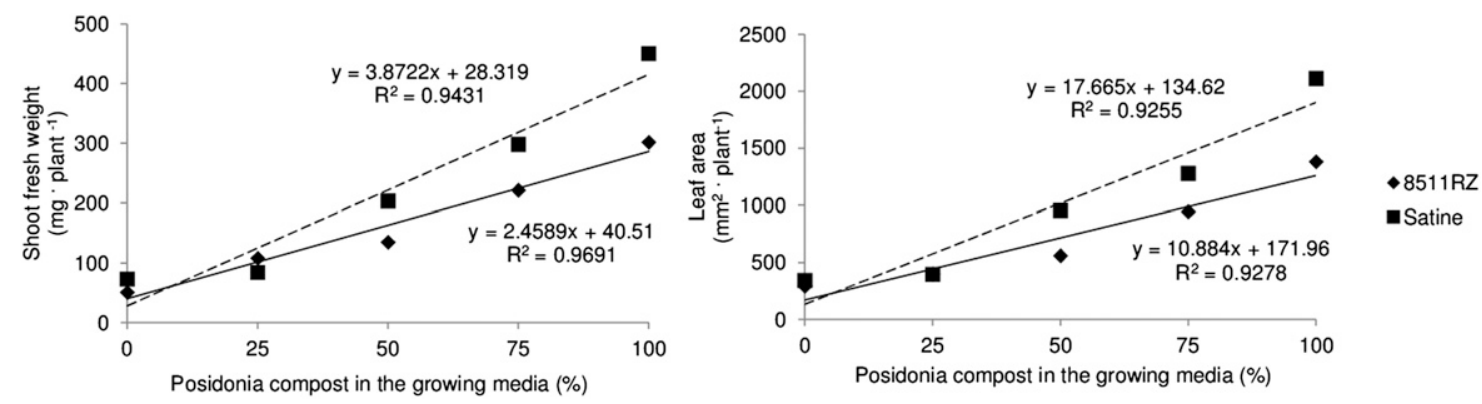

Fig. 1. Effects of posidonia-based compost presence in the growing substrate on shoot fresh weight and leaf area of '8511RZ' and 'Satine' lettuce seedlings. Each point is the mean of three replications. Lines indicate significant linear or quadratic effects. 
showed the highest overall concentration of nutrients in shoot tissues (Table 6). N, P, and $\mathrm{Zn}$ shoot concentrations increased linearly with increasing compost rate in the mixture, whereas $\mathrm{K}, \mathrm{Ca}, \mathrm{Mg}, \mathrm{Na}, \mathrm{Fe}, \mathrm{Cu}$, and $\mathrm{B}$

increased following a quadratic trend, in accordance with the relatively higher content of those elements in the growing media, with the exception of $\mathrm{N}$ and $\mathrm{K}$. Because $\mathrm{N}_{\text {tot }}$ content did not differ among growing media

Table 5. Root system morphology of the seedlings of two lettuce cultivars grown on five growing media with increasing posidonia-based compost percentage.

\begin{tabular}{|c|c|c|c|c|c|}
\hline & $\frac{\text { Length }}{(\mathrm{mm} / \text { plant })}$ & $\frac{\text { Area }}{\left(\mathrm{cm}^{2} / \text { plant }\right)}$ & $\frac{\text { Avg diam }}{(\mathrm{mm})}$ & $\frac{\text { Volume }}{\left(\mathrm{cm}^{3} / \text { plant }\right)}$ & $\frac{\text { Tips }}{\text { (no.) }}$ \\
\hline \multicolumn{6}{|l|}{ Cultivar (CV) } \\
\hline $8511 \mathrm{RZ}$ & 145 & 15.1 & 0.33 & 0.13 & 302 \\
\hline Satine & 223 & 23.3 & 0.33 & 0.20 & 412 \\
\hline \multicolumn{6}{|l|}{ Substrate $(S)^{z}$} \\
\hline $\mathrm{C} 0$ & 102 & 9.7 & 0.30 & 0.07 & 194 \\
\hline $\mathrm{C} 25$ & 147 & 14.0 & 0.30 & 0.11 & 268 \\
\hline $\mathrm{C} 50$ & 197 & 20.0 & 0.32 & 0.16 & 346 \\
\hline $\mathrm{C} 75$ & 220 & 23.6 & 0.34 & 0.20 & 400 \\
\hline C100 & 255 & 28.9 & 0.36 & 0.26 & 578 \\
\hline \multicolumn{6}{|l|}{ Significance ${ }^{y}$} \\
\hline $\mathrm{CV}$ & $* * *$ & $* * *$ & NS & $* * *$ & $* * *$ \\
\hline S contrasts & $\mathrm{L}^{* * *}$ & $\mathrm{~L}^{* * *}$ & $\mathrm{~L}^{* * *}$ & $\mathrm{~L}^{* * *}$ & $\mathrm{C}^{*}$ \\
\hline$C V * S$ contrasts & $\mathrm{L}^{*}$ & $\mathrm{Q}^{* *}$ & NS & $\mathrm{Q}^{* * *}$ & $\mathrm{Q}^{* *}$ \\
\hline
\end{tabular}

${ }^{\mathrm{z}} \mathrm{C} 0=100 \%$ peat-based commercial substrate; $\mathrm{C} 25=25 \%$ posidonia-based compost $+75 \%$ peat-based commercial substrate; $\mathrm{C} 50=50 \%$ posidonia-based compost $+50 \%$ peat-based commercial substrate; $\mathrm{C} 75=75 \%$ posidonia-based compost $+25 \%$ peat-based commercial substrate $; \mathrm{C} 100=100 \%$ posidoniabased compost. Percentages are expressed on the basis of volume.

${ }^{y}$ Linear (L), quadratic (Q) or cubic (C) effect. Ns, *, ${ }^{* *},{ }^{* * *}$ Nonsignificant or significant at the $5 \%, 1 \%$, or $0.1 \%$ level of probability, respectively.

Table 6. Shoot tissues mineral concentration (on dry matter basis) of the seedlings of two lettuce cultivars grown on five growing media with increasing posidonia-based compost percentage.

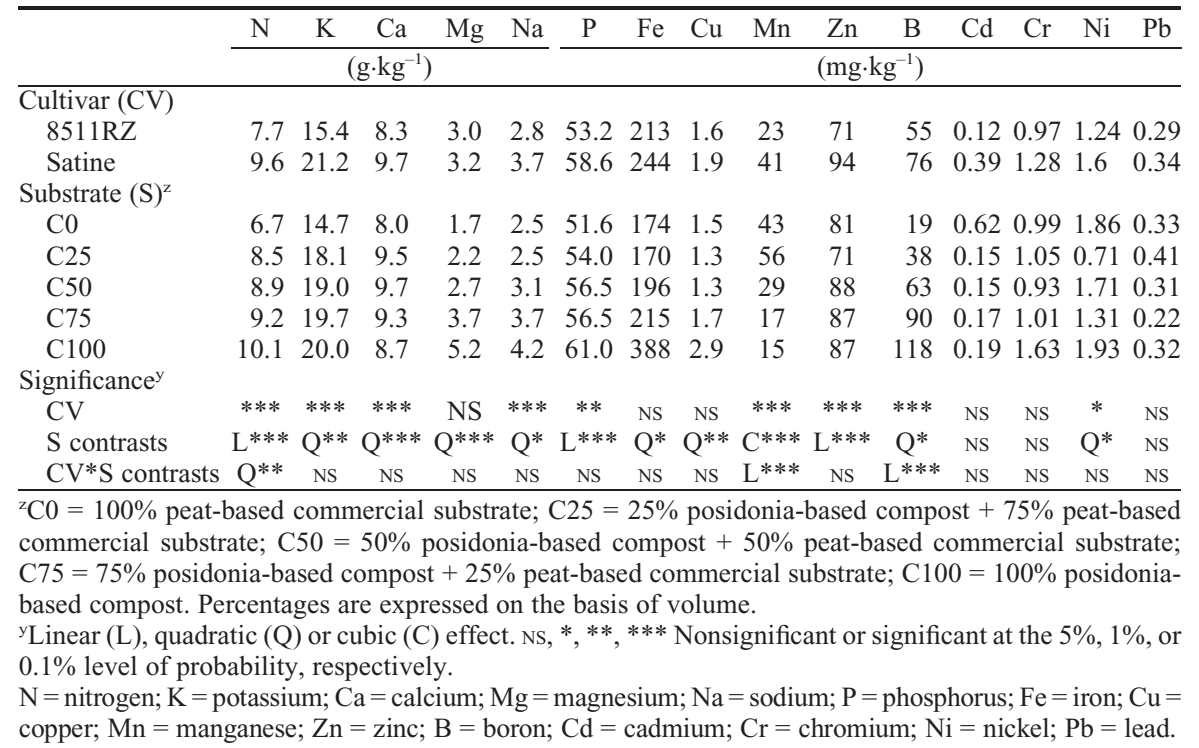

(Table 2), its higher concentration in plants grown on compost-based growing media was the result of the different quality of the organic matter of peat and compost with the latter one characterized by more simple residues (Cocozza et al., 2011a) that can mineralize easier, as revealed by the higher $\mathrm{N}-\mathrm{NO}_{3}$ concentration in the extracts (Table 3 ). According to Raven and Smith (1976), the relatively higher availability of $\mathrm{N}-\mathrm{NO}_{3}$ could have influenced the behavior of $\mathrm{K}$, because the uptake of one nitrate molecule has to be balanced with the uptake of a monovalent cation. Therefore, despite the fact that $\mathrm{K}$ was relatively more abundant in peat-based substrate (Table 2), its concentration was higher in plants grown on compost-based substrates. A decrease of Mn tissue concentration, more remarkable in 'Satine', was observed with increasing compost presence in growing media (Table 6; Fig. 3). Similar results have been reported by other authors (Ingram et al., 1993; Ribeiro et al., 1999, 2007) and are probably a consequence of the reduced $\mathrm{Mn}$ availability induced by the high $\mathrm{pH}$ values of these growing media as well as by the presence of humic-like compounds in the compost, which react with Mn (Ribeiro et al., 2007). The effect of compost addition on increasing uptake of nutrients was more remarkable in 'Satine' (Fig. 3). The possible explanation for the difference in the elemental composition of the two cultivars is in the most developed root system of 'Satine', which also showed an higher overall growth, biomass production, and consequently nutrient uptake, and, in general, in specific preferences, genotype-mediated for the absorption and assimilation of nutrients.

An important role in the higher nutrient uptake in the presence of compost could have been played by the increased growth of the root system, in particular in terms of surface area and number of tips.

Both cultivars showed slight symptoms of toxicity (necrosis of the margins in older leaves) in the last week of the cycle in C75 and $\mathrm{C} 100$ treatments, probably related to $\mathrm{B}$ toxicity as reported by Eraslan et al. (2007); in fact, the two treatments with highest percentage of composts showed the highest levels of B (Table 2). Interestingly, symptoms of $\mathrm{B}$ toxicity were not linked to reduced growth, typical of plants exposed to high B levels (Nable et al., 1990).
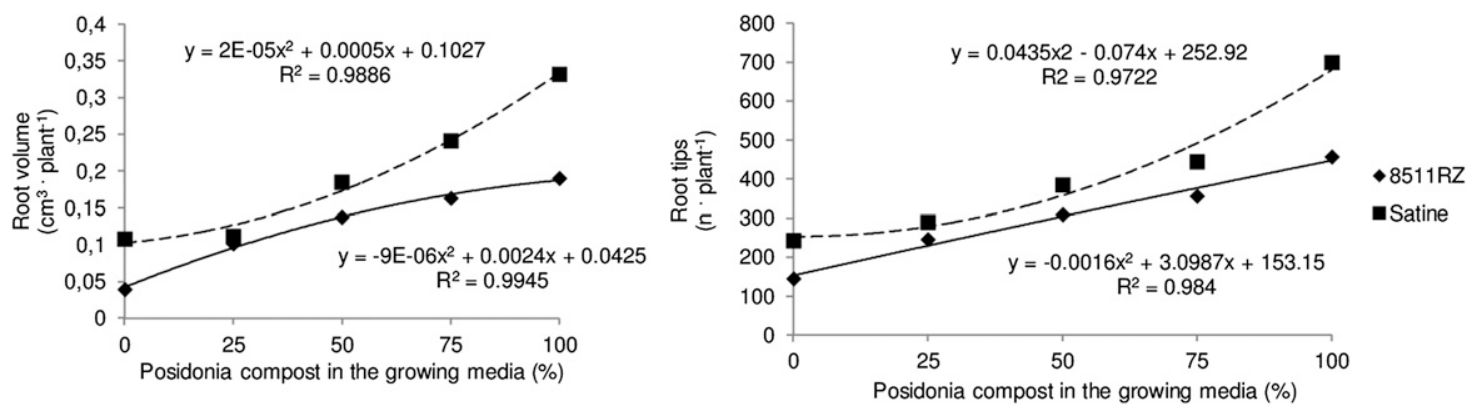

Fig. 2. Effects of posidonia-based compost presence in the growing substrate on root volume and root tips number of '8511RZ' and 'Satine' lettuce seedlings. Each point is the mean of three replications. Lines indicate significant linear or quadratic effects. 

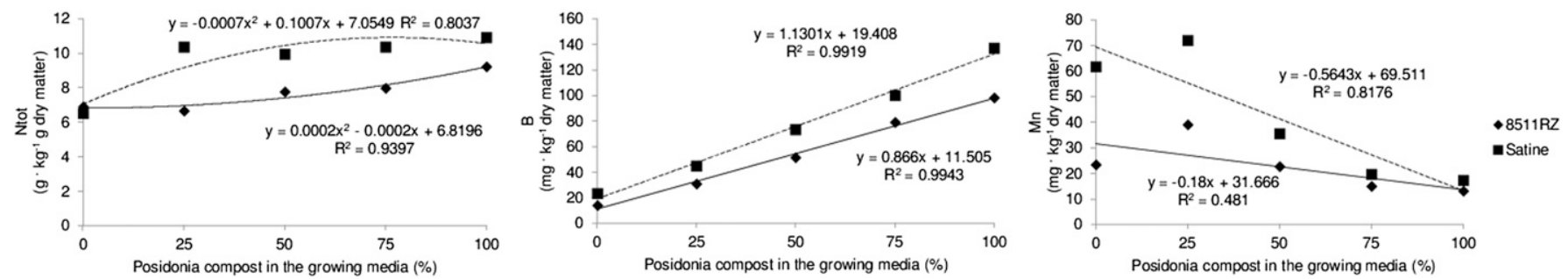

Fig. 3. Effects of posidonia-based compost presence in the substrate on total nitrogen ( $\mathrm{N}_{\mathrm{tot}}$ ), boron (B), and manganese (Mn) leaf tissues content of ' $8511 \mathrm{RZ}$ ' and 'Satine' lettuce seedlings. Each point is the mean of three replications. Lines indicate significant linear or quadratic effects.

In general $\mathrm{Cu}, \mathrm{Mn}, \mathrm{Zn}, \mathrm{Cd}, \mathrm{Cr}$, and $\mathrm{Pb}$ concentrations in tissues obtained from plants grown on compost-based growing media were lower than the ranges considered normal for plants (Adriano, 2001), thus suggesting safe use from that point of view.

Lettuce seedlings showed an enhanced overall growth with increasing presence of posidonia-based compost in the growing media in the absence of external fertilization. The Satine cultivar benefited most from the addition of compost respect to ' $8511 \mathrm{RZ}$ ' in terms of enhanced growth and nutrient uptake. In conclusion, results of the current experiment show that the posidonia-based compost has considerable potential for substituting peat in soilless growing media, in particular for the production of lettuce seedlings for the transplant. For its properties, posidonia-based compost can be considered a good alternative or be used as a complement to peat. The use of posidonia-based compost could reduce the input of mineral nutrients because of the natural endowment of the material. Although lettuce plants showed increasing overall growth proportional to the increasing percentage of posidonia-based compost in the growing media, this material should be used as a complement to peat at a rate of $50 \%$ to obtain the best physical properties and to limit its negative effects, possibly ascribed to the high B content, typical of posidonia debris.

\section{Literature Cited}

Abad, M., F. Fornes, C. Carrion, V. Noguera, P. Noguera, and A. Maquieira. 2005. Physical properties of various coconut coir dusts compared to peat. HortScience 40:2138-2144.

Abad, M., P. Noguera, and S. Bures. 2001. National inventory of organic wastes for use as growing media for ornamental potted plant production: Case study in Spain. Bioresour. Technol. 77: 197-200.

Adriano, D.C. 2001. Trace elements in terrestrial environment. Biochemistry, bioavailability and risks of metals. Springer, New York, NY.

Ben Jenana, R.K., M.A. Triki, R. Haouala, C. Hanachi, M. Ben Kheder, and B. Henchi. 2009. Composted posidonia, chicken manure and olive mill residues, an alternative to peat as seed germination and seedling growing media in Tunisian nursery. Pak. J. Bot. 41:3139-3147.

Bernal-Vicente, A., M. Ros, F. Tittarelli, F. Intrigliolo, and J.A. Pascual. 2008. Citrus compost and its water extract for cultivation of melon plants in greenhouse nurseries. Evaluation of nutriactive and biocontrol effects. Bioresour. Technol. 99: 8722-8728.
Bustamante, M.A., C. Paredes, R. Moral, E. Agullo, M.D. Perez-Murcia, and M. Abad. 2008. Composts from distillery wastes as peat substitutes for transplant production. Resour. Conserv. Recycling 52:792-799.

Castaldi, P. and P. Melis. 2004. Growth and yield characteristics and heavy metal content on tomatoes grown in different growing media. Commun. Soil Sci. Plan. 35:85-98.

Chavez, W., A. Di Benedetto, G. Civeira, and R. Lavado. 2008. Alternative soilless media for growing Petunia $\times$ hybrida and Impatiens wallerana: Physical behaviour, effect of fertilization and nitrate losses. Bioresour. Technol. 99:8082-8087.

Chong, C. 2005. Experience with wastes and composts in nursery substrates. HortTechnology 15 : 739-747.

Cocozza, C., A. Parente, C. Zaccone, C. Mininni, P. Santamaria, and T. Miano. 2011a. Comparative management of offshore posidonia residues: Composting vs. energy recovery. Waste Manag. 31:78-84.

Cocozza, C., A. Parente, C. Zaccone, C. Mininni, P. Santamaria, and T. Miano. 2011b. Chemical, physical and spectroscopic characterization of Posidonia oceanica (L.) Del. residues and their possible recycle. Biomass Bioenergy 35:799807.

De Boodt, M. and O. Verdonck. 1972. The physical properties of the substrates in horticolture. Acta Hort. 26:37-44.

De Falco, G., S. Simeone, and M. Baroli. 2008. Management of beach-cast Posidonia oceanica seagrass on the island of Sardinia (Italy, Western Mediterranean). J. Coast. Res. 24:69-74.

Duarte, C.M. 1991. Seagrass depth limits. Aquat. Bot. 40:363-377.

Duarte, C.M. 2004. How can beaches be managed with respect to seagrass litter? p.83-84. In: Borum, J., C.M. Duarte, D. Krause-Jensen, and T.M. Greve (eds.). European seagrasses: An introduction to monitoring and management. The M\&MS Project.

Eraslan, F., A. Inal, O. Savasturk, and A. Gunes. 2007. Changes in antioxidative system and membrane damage of lettuce in response to salinity and boron toxicity. Sci. Hort. 114:5-10.

EU Commission. 2001. Commission Decision of 28 Aug. 2001 establishing ecological criteria for the award of the Community eco-label to soil improvers and growing media (2001/688/ EC). Official Journal of the European Communities, L 242/17-L 242/22.

EU Commission. 2006. Commission Decision of 3 Nov. 2006 establishing revised ecological criteria and the related assessment and verification requirements for the award of the Community eco-label to growing media (2006/799/EC). Official Journal of the European Communities, L 325/28-L 325/34.

European Standard 13037. 1999. Determination of pH. In: Soil Improvers and Growing Media.
European Committee for Standardization, Brussels, Belgium.

European Standard 13038. 1999. Determination of electrical conductivity. In: Soil Improvers and Growing Media. European Committee for Standardization, Brussels, Belgium.

European Standard 13040. 1999. Sample preparation for chemical and physical tests, determination of dry matter content, moisture content and laboratory compacted bulk density. In: Soil Improvers and Growing Media. European Committee for Standardization, Brussels, Belgium.

Fonteno, W.C. 1996. Growing media: Types and physical/chemical properties, p. 93-122. In: Reed, D.W. (ed.). Water, media and nutrition for greenhouse crops. Ball Publishing, Batavia, IL.

Forde, B. and H. Lorenzo. 2001. The nutritional control of root development. Plant Soil 232:5168.

Gizas, G., I. Tsirogiannis, M. Bakea, N. Mantzos, and D. Savvas. 2012. Impact of hydraulic characteristics of raw or composted posidonia residues, coir, and their mixtures with pumice on root aeration, water availability, and yield in a lettuce crop. HortScience 47:896-901.

Grigatti, M., M.E. Giorgioni, and C. Ciavatta. 2007. Compost-based growing media: Influence on growth and nutrient use of bedding plants. Bioresour. Technol. 98:3526-3534.

Ingram, D.L., R.W. Henley, and T.H. Yeager. 1993. Growth media for container grown ornamental plants. FL. Coop. Ext. Serv. Bul. 241.

Intellectual Property in Australia. 2012. A seagrass based nutrient product for plant biological growth stimulation and a method for preparing the same-AU2007200687. <http://www. ipaustralia.com.au/applicant/van-schaiks-biogro-pty-ltd/patents/AU2007200687/>

Kjeldahl, J. 1883. A new method for the determination of nitrogen in organic matter. Z. Anal. Chem. 22:366-382.

Lazcano, C., J. Arnold, A. Tato, J.G. Zaller, and J. Domínguez. 2009. Compost and vermicompost as nursery pot components: Effects on tomato plant growth and morphology. Span. J. Agr. Res. 7:944-951.

López-Bucio, J., A. Cruz-Ramírez, and L. HerreraEstrella. 2003. The role of nutrient availability in regulating root architecture. Curr. Opin. Plant Biol. 6:280-287.

Marschner, H. 1995. Mineral Nutrition of Higher Plants. 2nd Ed. Elsevier Academic Press, London, UK.

Mininni, C., A. Parente, and P. Santamaria. 2009 Indagine sulla diffusione in Puglia dei residui spiaggiati di posidonia p. 43-78. In: Parente, A. and P. Santamaria (eds.). Il caso dei residui spiaggiati di posidonia oceanica: Da rifiuto a risorsa. Levante Editori, Bari, Italy [in Italian].

Nable, R.O., B. Cartwright, and R.C. Lance. 1990. Genotypic differences in boron accumulation in barley: Relative susceptibilities to boron 
deficiency and toxicity, p. 243-251. In: El Bassam, N., M. Dambroth, and B. Loughman (eds.). Genetic aspects of plant mineral nutrition. Kluwer Academic Pub., Dordrecht, The Netherlands.

Olsen, S.R., C.V. Cole, F.S. Watanabe, and L.A Dean. 1954. Estimation of available phosphorus in soil by extraction with sodium bicarbonate. USDA Circ. 939.

Orfeo, D. and L. Orlandi. 2009. I substrati di coltivazione in Italia. Il mercato italiano, p. 6-25. In: Zaccheo, P. and C. Cattivello (eds.). I substrati di coltivazione. Edagricole, Bologna, Italy [in Italian].

Orquin, R., M. Abad, P. Noguera, R. Puchades, and A. Maquieira. 2001. Composting of Mediterranean seagrass and seaweed residues with yard waste for horticultural purposes. Acta Hort. 549:29-36.

Ott, J.A. 1980. Growth and production in Posidonia oceanica (L.) Del. March Ecol. 1:47-64.

Perez-Murcia, M.D., R. Moral, J. Moreno-Caselles, A. Perez-Espinosa, and C. Paredes. 2006. Use of composted sewage sludge in growth media for broccoli. Bioresour. Technol. 97: 123-130.

Qazi, M.A., M. Akram, N. Ahmad, J.F. Artiola, and M. Tuller. 2009. Economical and environmental implications of solidwaste compost applications to agricultural fields in Punjab, Pakistan. Waste Mgt. 29:2437-2445.

Raven, J.A. and F.A. Smith. 1976. Nitrogen assimilation and transport in the vascular land plants in relation to intracellular $\mathrm{pH}$ regulation. New Phytol. 76:415-431.
Redjala, T., I. Zelko, T. Sterckeman, V. Legué, and A. Lux. 2011. Relationship between root structure and root cadmium uptake in maize. Environ. Exp. Bot. 71:241-248

Ribeiro, H.M., D. Ribeiro, E. Vasconcelos, F. Cabral, V. Louro, and J.Q. Santos. 1999. Evaluation of a sewage sludge based compost for the production of container tree seedlings, p. 181-184. In: Anaç, D. and P. Martin-Prével (eds.). Improved crop quality by nutrient management. Kluwer Academic Publishers, Dordrecht, The Netherlands.

Ribeiro, H.M., A.M. Romero, H. Pereira, P. Borges, F. Cabral, and E. Vasconcelos. 2007. Evaluation of a compost obtained from forestry wastes and solid phase of pig slurry as a substrate for seedlings production. Bioresour. Technol. 78: 3294-3297.

Saidi, N., S. Kouki, F. M'Hiri, N. Jedidi, M. Mahrouk, A. Hassen, and H. Ouzari. 2009. Microbiological parameters and maturity degree during composting of Posidonia oceanica residues mixed with vegetables wastes in semi-arid pedoclimatic conditions. J. Environ. Sci. (China) 21: 1452-1458.

Sánchez-Monedero, M.A., A. Roig, J. Cegarra, M.P. Bernal, P. Noguera, M. Abad, and A Antón. 2004. Composts as media constituents for vegetable transplant production. Compost Sci. Util. 12:161-168.

Springer, U. and J. Klee. 1954. Prufung der Leistungfahigkeit von einigen wichtigen verfaren zur Bestimmung des Kohlenstoffe mittels Chromschwefelsaure sowie Vorschlag einer neuen Schnellmethode. <http://www3. interscience.wiley.com/journal/117943132/ home $>64: 1-26$ [in German].

Steel, R.G. and J.H. Torrie. 1988. Principles and procedures of statistics. 2nd Ed. McGraw-Hill, New York, NY.

Sterrett, S.B. 2001. Compost as horticultural substrates for vegetable transplant production, $\mathrm{p}$ 22-240. In: Stovella, P.J. and B.A. Kahn (eds.). Compost utilization in horticultural cropping systems. Lewis, Boca Raton, FL.

Taylor, H.M. and L.F. Ratliff. 1969. Root elongation rates of cotton and peanuts as a function of soil strength and soil water content. Soil Sci. 108:113-119.

Tremblay, N. and M. Senècal. 1988. Nitrogen and potassium in nutrient solution influence seedling growth of four vegetable species. HortScience 23:1018-1020.

Tsakaldimi, M. 2006. Kenaf (Hibiscus cannabinus L.) core and rice hulls as components of container media for growing Pinus halepensis M. seedlings. Bioresour. Technol. 97:16311639 .

Verlodt, H., A. Ben Abdallah, and Y. Harbaoui. 1984. Possibility of reutilization of a composted substrate of Posidonia oceanic (L.) Del. in a tomato growth bag. Acta Hort. 150:439-448.

Weston, L.A. and B.H. Zandstra. 1986. Effect of root container size and location of production on growth and yield of tomato transplants. J. Amer. Soc. Hort. Sci. 111:498-501.

Zaccheo, P. and C. Cattivello. 2009. I substrati di coltivazione. Aspetti teorici ed applicativi di un fattore chiave delle produzioni in contenitore. Edagricole, Bologna, Italy [in Italian]. 